\title{
Intellectual Property Piracy and Counterfeiting in Nigeria: The Impending Economic and Social Conundrum
}

\author{
K.M WAZIRI \\ Faculty of Law, Department of Private \& Islamic Law \\ University of Abuja, Nigeria \\ Tel: 234-80-3315-3247_E-mail: kmwaziri2003@yahoo.com
}

Received: April 2, 2011

Accepted: June 7, 2011

doi:10.5539/jpl.v4n2p196

\begin{abstract}
Nigeria's status as a favourable destination for foreign direct investment as well as a place where local creative talent can flourish is in jeopardy due to the activities of individuals that place no value on intellectual property (IP). Experts have highlighted that one major snag to development of intellectual property in Nigeria is piracy and counterfeiting. It has ripped off many producers, manufacturers, artists, marketers and stakeholders of the benefits of their creativity and also prevented the industry from rapid financial growth and development. It is in this light that we intend to look at the place of piracy and counterfeiting to the social and economic development in Nigeria.
\end{abstract}

Keywords: Intellectual property, Piracy, Counterfeiting, the Economy

\section{Introduction}

Pirated and counterfeit products, have contributed to high intellectual property theft. Fake and pirated products, though a global problem plaguing most developing countries, has become a cankerworm which the Nigerian government needs to fight against if it must make headway in its drive for economic independence and progression. It is a strong factor that will hinder the country's many developmental programmes and its Vision 2020 if not properly addressed.

Counterfeit and pirated products cut across virtually all areas of human consumer goods, including drug, food, books, electrical parts, compact disc, textile material and foot wears, among others. According to experts, it has not only become an instrument of mass destruction, but has ripped many of the dividends of their intellectual property rights. Unfortunately, most of the world's bogus drugs and pirated products originate from Asia, particularly China, according to the U.S. Centre for Medicine in the Public Interest. The fakes oftentimes are exported and they change hands many times before reaching their unwitting consumers. The growing trade has been fuelled by internet sales and the lure of lucrative profits.( Note 1 )

Piracy and counterfeiting describe the sale of copies of products without the permission of the owner of the rights to those products. Piracy usually refers to the sale of unauthorized copies, without necessarily claiming that it is an authorized copy. For example, selling a recording of a movie made by someone sitting in a theatre with a video camera is a type of piracy. Counterfeiting means selling a copy that looks like an authorized copy and falsely claiming that it was authorized or licensed, such as selling unauthorized or unlicensed copies of software in a package that looks exactly like a legitimate package. Some counterfeit copies of products may be so accurate that it is difficult to tell them from the legitimate product. (Note 2)

The most common types of piracy and counterfeiting internationally include: Medications, Apparel, footwear and handbags, Movies and music, Auto parts, Electronics, Health products (toothpaste, lotion, and vitamins), Food, alcohol and beverages etc.

According to the chairman, Longman Nigeria Plc, Emmanuel Ijewere, authors and producers in the entertainment industry have been impoverished in the last 20 years, as they lost over N81 billion to counterfeiting and piracy. He explained that Nigerians spent over N90 billion in purchasing books and pirated compact disc within the period, but regretted that only N8-billion went into the coffers of the producers. Ijewere said that authors are no longer encouraged to write, since they will end up making more money for counterfeiters and pirates, stressing that Nigeria will not make any headway unless the Nigerian Copyright Commission rises to the occasion. The chairman therefore called on the Nigeria Customs Service to ensure that anybody importing books, compact disc and other materials is 
registered with the Nigerian Copyright Commission, in order to reduce the number of pirated items coming into the country. ( Note 3)

Recounting the after effect of counterfeit to the Nigerian textile industry, the United Nation Industrial Organisation (UNIDO) representative in Nigeria, Sodhi Navdeep, said over 70,000 Nigerians working in the textile industries have lost their jobs since the year 2000, due to accelerated closure of many manufacturing firms, while the surviving ones are in the state of comatose. The Chinese counterfeited products specifically target and copy the trade marks of Nigerian textile manufacturers and brand their product Made in Nigeria or Made as Nigeria and even blatantly fake Standard Organisation of Nigeria or Nigerian Industrial Standard markings to deliberately mislead consumers. Presently, he said fake Chinese products occupy 80 percent of market share in Nigeria.

Navdeep explained that the remaining 24,000 workers of the existing textile industry are in the intensive care unit, stressing that greater awareness should be created among the stakeholders about its damaging effect on the economy, as well as the urgent need to check trade practices. Navdeep suggested that the Federal Government should engage the Chinese authorities by drawing their attention to the serious damage caused by the trade malpractices of their textile exporters to the Nigerian economy. ( Note 4)

Preventing and punishing piracy and counterfeiting of intellectual property is impossible for any one country to do on its own. For example, many unscrupulous vendors make or distribute unauthorized copies of products that find their way into the US market. But since these vendors operate beyond the territorial reach of US law enforcement, and the authorities in the vendors' own countries often do not assign a high priority to catching or prosecuting intellectual property thieves, the vendors continue to profit from counterfeited and pirated goods. (Note 5)

\section{Definition of Terms}

\subsection{PIRACY}

Piracy is the unauthorized and illegal reproduction or distribution of materials protected by copyright, patent, or trademark law. (Note 6) The test of piracy is not whether the identical language, the same words, are used, but whether the substance of the production is unlawfully appropriated( Note 7).

In other words, it is the unlawful copying and distribution of copyrighted works such as software or recordings of music. (Note 8)

Also, it is the Illegal and unauthorized copying or distributing materials protected under copyright, trademark, or patent law. (Note 9)

\subsection{Counterfeiting}

Counterfeiting is ultimately an infringement of the legal rights of an owner of intellectual property. (Note 10) Counterfeiting is defined as: To unlawfully forge, copy, or imitate an item . . . or to possess such an item without authorization and with the intent to deceive or defraud by presenting the item as genuine. (Note 11)

A counterfeit mark is a spurious mark that is used in connection with trafficking in goods or services that is identical with, or substantially indistinguishable from a mark in use and registered on the principal register for those goods or services and the use of which is likely to cause confusion, mistake or deceive. (Note 12)

The World Intellectual Property Organization (WIPO) and the Trade-Related Aspect Intellectual Property Rights (TRIPS) agreement defines a counterfeit trademark good as: any goods, including packaging, bearing without authorization a trademark which is identical to the trademark validity registered in respect of such goods, or which cannot be distinguished in its essential aspects from such a trademark, and which thereby infringes the rights of the owner of the trademark in question under the law of the country of importation. (Note 13)

The term "counterfeiting" and "piracy" in relation to goods refer to the manufacture, distribution and sale of copies of goods which have been made without the authority of the owner of the intellectual property. These goods are intended to appear to be as similar to the original as to be passed off as genuine items. This includes use of famous brands on pharmaceutical products, clothing, perfumes, and household products, not manufactured by or on behalf of the owner of the product, as well as exact copies of CDs containing music or software, which are traded in a form intended to be indistinguishable to ordinary consumers from the genuine product. In a criminal law context, intellectual property counterfeiting is defined as contraband activities which centre on the illegal production and sale of goods which are intended to pass for the real product. (Note 14)

\section{Counterfeiting and Piracy: The Nigerian Economy}

While piracy accounts for almost $7 \%$ of all global trade, Nigeria accounts for $80 \%$ of the pirated international music CDs. (Note 15) This trend has a subsistent damaging effect on the Nigerian economy and global trade. 
In sub-Saharan Africa for instance, according to Business Software Alliance (BSA), the highest piracy countries were Zimbabwe 92\% Cameroon 83\% and Nigeria 83\%. Among the lowest piracy countries were Reunion- 40\%, Mauritius$57 \%$ and Senegal-79\%. Also the (BSA) revealed that software piracy on personal computers (PC) in Nigeria has risen to $1 \%$ from 2007 to 2008 . Half of the 110 countries studied, according to BSA, saw piracy rates drop while only $15 \%$ increased. The report also revealed that industry losses due to software piracy in Nigeria rose to USD132 million in 2008.

Dale Waterman, Vice Chair, BSA Middle East and Africa Committee said: "This report demonstrates the amount of work that we still need to do in Nigeria to further reduce software piracy," he added: "In these uncertain economic times it is vital that companies do not cut corners by using unlicensed software as this would increase the detrimental impact on those businesses, consumers as well as the local and global economy."

The former Director General of The Nigeria Copyright Commission (NCC), Adebambo Adewopo has earlier raised alarm on the economic implication of the ugly trend noting that, "tackling piracy and ensuring Intellectual Property rights are protected is top priority for us. The growing presence of extremely sophisticated counterfeit software in our market indicates the existence of organized crime syndicates, perhaps from outside Nigeria threatening to undermine our ICT economy through their activities. It is more crucial than ever that we remain vigilant and committed to tackling these criminals." (Note 16)

Software piracy affects much more than just industry revenues. A study released in January 2008 by IDC, the information technology (IT) industry's leading global market research and forecasting firm found that reducing software piracy could generate hundreds of thousands of new jobs, and billions of dollars in economic growth across the most vulnerable regions, while increasing tax revenues to support local programs and services.

Similarly, speaking further on the implications for Nigerian economy, Intellectual Property Manager for Microsoft Nigeria, Mr. Serge Ntamack warned on the effect saying: "Piracy is so endemic in our environment, affecting every industry that is built on intellectual property assets. This includes the music, movie, software and book publication industries. Each of these industries has the potential to contribute millions of dollars to the economy if the threat of piracy is addressed decisively."

In the face of the current economic challenges, the government and all other stakeholders must work together to create an enabling environment for people to apply their creativity to developing new sources of revenue that will mitigate our current dependence on oil. The local software industry can only grow in an environment less fraught with piracy. BSA advocates a five point blueprint for reducing software piracy and reaping the economic benefits:

a. Increase public education and awareness of the value of intellectual property and the risks of using unlicensed software;

b. Update national copyright laws to implement World Intellectual Property Organisation (WIPO) obligations in order to enable better and more effective enforcement against digital and online piracy;

c. Create strong enforcement mechanisms as required by the WTO Trade Related Aspects of Intellectual Property Rights Agreement (TRIPS), including tough antipiracy laws;

d. Dedicate significant government resources to the problem, including national IP enforcement units, cross border cooperation, and training for local officers and judiciary officials; and

e. Lead by example by implementing software management policies and requiring the public sector to use only legitimate software.

On its part, Microsoft has been proactive in tackling piracy on three fronts including IPR awareness, driving a government lobby to implement stricter IPR laws and addressing the channel issues to ensure availability. (Note 17)

The Nigerian Copyright Commission (NCC) in a statement sometime in December, 2007 said that the film industry loses an estimated N4, 200, 000,000 annually to illegal digital duplication, on-line piracy and unauthorized rental of video works within the country. A report by the Nigerian Television Authority (NTA) in august, 2008, estimated the total annual loss of the content industries (Music Software and Video) within the nation to be well over $\mathrm{N} 100$, 000,000,000. (Note 18)

Also in January, 2008, the Director of Filmmakers Association of Nigeria (FAN), Mrs. Pat Okolo stated that the country loses an estimate of N4,000,000 to international piracy of Nigerian movies in America, Canada and Europe. Okolo also suggested that there is an urgent need to organize marketing and distribution strategy internationally to eliminate piracy and repatriate money and efforts back into the Nigerian economy. Recently, artists and producers rallied at the national stadium, Lagos, for what they referred to as "HUNGER STRIKE". They sought means to vent their anger, but one pertinent question that begs for an answer is: how successful has the campaign against piracy been 
in the last one decade? Piracy is so bad in Nigeria that local artists and filmmakers now refuse their latest albums and movies into the retail market. Reports from neighbouring countries suggest that large quantities of pirated discs are being exported from Nigeria across the region.

The intellectual property system is the only way of protecting the creativity of authors and ensuring that the nation's intellectual treasures and the resulting economic derivation are better secured. Lack of adequate protection over time, has resulted in direct economic loss to right owners while government is denied revenue from legitimate products. This is in addition to the obvious moral and ethical reasons against unjust enrichment, intellectual theft and fraudulent claims that characterize piracy and other intellectual property abuses.

There is a preponderance of opinion amongst experts that a modern and well managed intellectual property system could be a catalyst for economic reform. With a huge population of over 150 million people, Nigeria is likely to generate more revenue in the exploitation of its intellectual property. (Note 19)

Citing example of the implication of fake drug in Nigeria, CNN's Sanjay Gupta, reported the case of Nneka and Chimezie Ononaku, a couple in Nigeria who unwittingly and unknowingly poisoned their infant son after feeding him teething medicine that was contaminated and antifreeze. Counterfeit drugs he pointed out can be almost impossible to spot, but can contain inactive ingredients like talcum powder, or even toxic ingredients such as rat poison. According to Prof. (Mrs.) Dora Akunyili, the former director general of the National Agency for Food and Drug Administration and Control (NAFDAC), counterfeit drug is one of the greatest challenges Nigeria is facing. According to her, over 50 percent of drugs and food drinks sold in Ariaria Market in Aba, Onitsha Market, Alaba Market, among other markets across the country are counterfeit, stressing that many families have been wiped away due to after effect of this deadly medications and consumable goods. NAFDAC she said is winning the war, explaining that more still need to be done by government and individuals to eradicate this menace, because anybody can be a victim. (Note 20)

\section{Problems of Intellectual Property in Nigeria}

Piracy and counterfeiting have for so long remain a major problem in Nigeria due to the weak enforcement of the intellectual property law. Below are at least six factors that militate against an effective enforcement of intellectual property laws in Nigeria:

\subsection{Lack of Population Support or Public Consultation}

Essentially, the Copyright Act and the Trademarks Act which are the primary legislative tool for copyright and trademark protection in Nigeria today, were adopted without broad-based public discussion on the necessity for copyright and trademark protection or the scope of protection that was desirable contrary to paragraph 9 of the Adelphi Charter on Creativity, Innovation and Intellectual Property which states that in making decisions about intellectual property laws, "there should be wide public consultation." (Note 21)

\subsection{INADEQUATE COST-BENEFIT ANALYSIS:}

An effective intellectual property regime must strike an appropriate balance between the monopoly powers of creators and the interest of the consuming public. In developed countries, the adoption of intellectual property laws is usually preceded by a detailed analysis of the cost and benefits of protection. Indeed, paragraph 2 of the Adelphi Charter states that "the public interest requires a balance between the public domain and private rights. It also requires a balance between the free competition that is essential for economic vitality and the monopoly rights granted by intellectual property laws." Sadly, laws in Nigeria are frequently passed without serious attention to the direct and indirect cost of a proposed legislation. There is need for serious economic assessment of the costs and benefits of copyright and trademark protection in Nigeria.

\subsubsection{Lack of Public Awareness:}

There is little public awareness or understanding of the intellectual property laws in the country. Existing laws are not readily accessible even to the educated class. The average man on the street is also ignorant of touted benefits of intellectual property protection. The Nigerian copyright commission admits that lack of awareness about the laws and administration of copyright constitutes "a major inhibition to the development of a sound copyright system in Nigeria." Meaningful public education at the grassroots level must form a critical component of intellectual property enforcement in Nigeria.

4.2.2 Lack of Inclusion in Law School Curriculum:

Structured legal education on intellectual property law must also be part of the equation. How many universities offer courses on intellectual property law? How many university libraries are equipped with basic books relating to intellectual property? Presently, very few lawyers in Nigeria have expertise in the field and only a handful of universities in the country offer courses in this area. One solution could be for the Nigerian government to tap into the expertise of Nigerians in the Diaspora. There are many Nigerians abroad with expertise in intellectual property law 
who are willing to return to Nigeria to help strengthen the course offerings of law faculties in the country for little or no compensation.

\subsubsection{Corruption and Weak Custom Enforcement:}

Attention must also be paid to the effect of corruption on intellectual property enforcement in Nigeria. Responsible agencies are rarely, if ever, audited or probed. There is need for accountability on the part of agencies challenged with the task of enforcing the countries intellectual property laws. For example, Nigerian ports are the principal gateways through which pirated and counterfeited imports come into the country and pirated and counterfeited exports leave. What has been the record of the Nigerian Custom Services in terms of interdiction? How does bribery and corruption undermine the enforcement capacity of the Nigerian Custom Service or the police? Proffering answers to these questions will indeed go a long way to salvage the economy. (Note 22)

\subsubsection{Judicial Enforcement:}

Delays in the judicial system and other barriers to justice also discourage intellectual property litigation and enforcement in Nigeria. Because intellectual property law is not taught in many universities in Nigeria, few judges in the country have knowledge about this area of law. The libraries of most courts in Nigeria are grossly inadequate too. One solution would be to create continuing legal education seminars for our judges. Such targeted training seminars could be organised by the Nigerian Bar Association, perhaps in cooperation with the American Bar Association.

\subsubsection{Lack of Well Trained Personnel}

The director general of the Nigerian Copyright Commission, Adebambo Adewopo on his part, stated customs is facing challenges because of the CEMA, explaining Cap 45 of their law did not make provisions for the enforcement and prosecution anybody impounded with counterfeit and pirated materials. He pointed out that lack of knowledge and training of officers is posing problem of enforcement of intellectual property by the Nigeria Customs Service, expressing dissatisfaction that in the last 15 years, no customs officer has been trained by Nigerian Copyright Commission, as was the practice before. As for him, counterfeiting and piracy needed to be checkmated because of the dwindling oil revenue. (Note 23)

\section{Conclusion}

Counterfeiting and piracy poses a tremendous threat to the prosperity of one of Nigeria's most vibrant economic sectors: its creative and innovative industries. Accordingly, it deserves our utmost attention. This attention must be lasting and consistent if it is to be successful because the protection of intellectual property is cardinal and premised on accepted moral, economic considerations. As a fundamental rule of natural justice, every man should be guaranteed the fruits of his labour. While it is not realistic to expect to eliminate all counterfeit and piracy in the shortest time, I do believe that we can strive to improve the situation, to the benefit of authors and right-holders, manufacturers and indeed local industries here in Nigeria and throughout the world.

\section{Recommendation}

Can Nigeria afford protection to artists, musicians and film makers, creative works and at the same time preserve the country's public domain? To effectively protect creative works generated by the entertainment industry, the government must address the widely held belief that intellectual property protection is a Western concept irrelevant in Africa. Debate about whether and to what extent Nigerian artists and musicians deserve copyright protection must be divorced from the broader debate about the merits and demerits of global strengthening of IP rights. The government must also seriously address the numerous factors that undermine effective enforcement of laws in the country including corruption, lack of coordination among the responsible agencies, lack of accountability, and lack of resources. However, for enforcement to make sense and be effective, the underlying law must be appropriate, balanced, understood by the general public, and a product of broad-based debate and participation.

Speaking on why counterfeit and piracy are thriving in Nigerian, the former Minister of Finance, Mansur Muktar, said that the Nigeria Customs Service obsolete law has failed to provide the legal framework and tools that makes the organisation a portent agency for the enforcement of Federal government trade and fiscal policies. He explained that the present day Customs and Excise Management Act (CEMA) is expected to provide a strong umbrella to protect and strengthen Nigerian talents, innovators and manufacturers to sprout, nurtured and become competitive. Muktar regretted that counterfeit and piracy has continued to kill creativity, resourcefulness and competition, which is an abuse of intellectual property, stressing that amendment of the customs law would go a long way to checkmate this ugly trend in the country.

Sola Dosunmu, head, Commercial and Intellectual Property, British American Tobacco Nigeria (BATN), speaking on the way forward, he said Nigerian government should identify and litigate against all infringers of its intellectual property in order to send out a clear message that Nigeria is not a conducive environment for illicit trade. He called for 
effective administration of Standard Organisation of Nigeria Conformity Assessment Programme (SONCAP) whereby imports are checked for compliance at the point of export before shipments are made to Nigeria.

Dosunmu advised that the Consumer protection Council should assist at the ports and Nigeria's borders with neighbouring countries, to ensure that only imported consumer goods which are fit for Nigerian consumption are cleared. The legislature he said should ensure that national legislation protecting trademarks is also applicable to goods produced and shipped through the Free Trade Zones.

\section{References}

Blackwell, H. A. (2008). The Essential Law Dictionary. Naperville, Illinois. Sphinx Publishing.

Dibie, M. Nigeria. (2008). Piracy - Robber of Intellectual Property. Abuja: Nigeria, All Africa Global Media.

Drone, S. E. (1879). A treatise on the Law of Property in Intellectual Productions. 97.

Erondu, A. C. (2009). Menace of counterfeits and pirated products. Business day.

Garner, A. B. (1999). Blacks Law Dictionary (7 $7^{\text {th }}$ ed.) St. Paul Minn.: U.S.A. West Group Publishing Co..

Nigeria. (2009). Illegal Software Rises By One Percent As Microsoft Outlines Implications. Vanguard/All Africa

Global Media via COMTEX.

Ofodile, E. U. (2010). Nigerian Entertainment Industry and Piracy. University of Arkansas School of Law, Fayetteville, USA.

Osanyintuyi, S. (2009). Effects of Piracy in Nigeria. Yemi's Media.

Rubino, A. F. (2006). Intellectual Property Piracy FindLaw Thomson Business. 2009. Wild, E. S. Webster's New World Law Dictionary. Wiley Publishing Inc.

Ofodile, E. U. (2010). Nigerian Entertainment Industry and Piracy. University of Arkansas School of Law, Fayetteville, USA. (Online) Available: http://www.uchee@uark.edu

WIPO. Counterfeiting and Piracy. First Global Conference on Combating Counterfeiting. Fact Sheet: The Impact and Scale of Counterfeiting. Online Available: http://www.anti-counterfeitcongress.org

WIPO. Counterfeiting and Piracy. First Global Conference on Combating Counterfeiting. Fact Sheet: The Impact and Scale of Counterfeiting. Online Available: http://www.anti-counterfeitcongress.org

Blackwell, H. A. (2008). The Essential Law Dictionary. Naperville, Illinois. Sphinx Publishing.

Wild, E. S. (2006). Webster's New World Law Dictionary. Wiley Publishing Inc.

www.allwestafrica.com

www.anti-counterfeitcongress.org

www.businessdayonline.com

www.frankrubino.com

\section{Notes}

Note 1. Erondu, A.C. (2009) Menace of counterfeits and pirated products. (Online), Available: http://www.businessdayonline.com

Note 2. Rubino, A. F. (2009) Intellectual Property Piracy FindLaw Thomson Business. (Online)Available: http://www.frankrubino.com

Note 3. Erondu, A.C. Op cit.

Note 4. Ibid

Note 5. Rubino, A. F., Op cit.

Note 6 Garner, A. B. (1999) Blacks Law Dictionary (7th ed.) St. Paul Minn.: U.S.A. West Group Publishing Co..

Note 7. Drone, S. E. (1879) A treatise on the Law of Property in Intellectual Productions.Boston, Little, Brown, and Company. 97

Note 8. Blackwell, H. A.( 2008). The Essential Law Dictionary. Naperville, Illinois. Sphinx Publishing,

Note 9. Wild, E. S. (2006).Webster's New World Law Dictionary. Wiley Publishing Inc.

Note 10. Ms Hema, Vithlani. of the ICC Counterfeiting Intelligence Bureau, for the Industry Division of the Economic Impact of Counterfeiting Organization for Economic Co-operation and Development Organization de Coopération et de Développement Economiques, Directorate for Science, Technology and Industry. It was initially presented to the Industry Committee on 12-13 March 1997 and subsequently revised; Woosnam, Peter (1997), "Customs: Your Ally in Combating Counterfeiting”, World Customs Organization, paper presented at the PIRA Conference on Product Counterfeit Protection, United Kingdom.

Note 11. Black’s Law Dictionary (2006) 376 (8th ed. 2004). 18 U.S.C. § 2320

Note 12. The Trademark Counterfeiting Act of (1984).

Note 13. WIPO "Counterfeiting and Piracy". First Global Conference on Combating Counterfeiting. Fact Sheet: The Impact and Scale of Counterfeiting. (Online) Available: http://www.anti-counterfeitcongress.org 
Note 14. By Professor Michael Blakeney, (2005) Queen Mary’s College, University of London.

Note 15. Dibie, M. (2008) Nigeria: Piracy - Robber of Intellectual Property. Abuja: Nigeria, All Africa Global Media.. sirc.blogspot.com

Note 16. Nigeria: Illegal Software Rises By One Percent As Microsoft Outlines Implications. Vanguard/All Africa Global Media via COMTEX. 2009. www.allwestafrica.com

Note 17. Ibid

Note 18. Osanyintuyi, S. (2009) Effects of Piracy in Nigeria. Yemi’s Media. (Online) Available:http://www.nigeriafilms.com

Note 19. Ibid

Note 20. Erondu A.C. Op cit.

Note 21. Ofodile, E. U. (2010) Nigerian Entertainment Industry and Piracy. University of Arkansas School of Law, Fayetteville, USA.(Online). Available: http://www.uchee@uark.edu

Note 22. Ibid

Note 23. Erondu A.C., Op cit. 